\title{
Ethnobotanical Study and Distribution of the Solanum Section Solanum Species (Solanaceae) in Iran
}

\author{
Eskandari M (Ph.D. Student) ${ }^{1,3}$, Assadi M (Ph.D.) ${ }^{2}$, Shirzadian S (Ph.D.) ${ }^{3}$, \\ Mehregan I (Ph.D.) ${ }^{1 *}$ \\ 1- Department of Biology, Science and Research Branch, Islamic Azad University, \\ Tehran, Iran \\ 2- Research Institute of Forests and Rangelands, Agricultural Research, Education \\ and Extension Organization (AREEO), Tehran, Iran \\ 3- Department of Botany, Iranian Research Institute of Plant Protection, Agricultural \\ Research, Education and Extension Organization (AREEO), Tehran, Iran \\ * Corresponding author: Department of Biology, Science and Research Branch, \\ Islamic Azad University, Tehran, Iran \\ Tel: +98-21-44865327 Fax: +98-2144265001 \\ E-mail: imehregan@ srbiau.ac.ir
}

Received: 17 Sep. 2019

Accepted: 28 Jan. 2019

doi: $10.29252 / \mathrm{jmp} .3 .71 .85$

\section{Abstract}

Background: Solanum section Solanum has been extensively used in traditional medicine in Iran for many ailment treatments. The plant contains some substances such as total alkaloid, steroid alkaloid, steroidal saponins and glycoprotein, exhibiting anti-tumor activity.

Objective: In this research, wild species of Solanum section Solanum has been studied in Iran in the field of ethnobotanical investigation such as interviews, questionnaires, scientific articles, authentic books and ancient documents in traditional medicine. The anthropological uses of the plant have also been taken into consideration.

Method: The wild species of these plants in Iran were studied using field and library methods. In the first method, to determine the distribution of Solanum and its related plants, numerous trips were carried out and many samples were collected. The anthropological use of these plants has been examined through interviews and questionnaires from 39 local people. In the second method, traditional Iranian books and published articles on the subject were also studied.

Results: According to this survey, these plants are commonly used for food digestion and constipation in traditional as well as current local medicine. In addition, we identified 180 different growing locations in Iran to illustrate their distribution maps.

Conclusion: These plants are being used as fever-reducing agent, pain-reliever, softener, laxative, diarrhea, anticoagulant and anti-asthma. Some outstanding results are obtained in the treatments of analgesic and sedative, anemia, burns, carminative, constipation, cough, cut restoration, food digestion, infections, mouth disinfection, skin diseases, toothache etc.

Keywords: Solanum nigrum, $S$. villosum, Black nightshade, Red nightshade, Solanaceae, Yellow nightshade 


\section{Introduction}

Ethnobotany is a type of scientific study in the field of botany and pharmacology that seeks to review, record, introduce and document information about the traditional usage of medicinal plants by indigenous people and ethnic groups in traditional, rural and nomadic areas around the world. Many plants in different villages and areas of Iran have different pharmaceutical uses that are not considered in many books of medicinal herbs and scientific papers. These plants which are very effective in their use are known only by experienced people, which have drug use in rural areas of the country.

Till now, information about the traditional uses of these plants has been transferred from one generation to other. Despite the expansion of modernity, this information is unfortunately disappearing. Therefore, ethnobotanical study helps documenting information before being completely disappeared.

Iran, is very diverse in terms of climate, and has over 8,000 native species out of which $20 \%$ are endemics. The collection of these plants has led to the establishment of a large number of plant species in different parts of Iran, each of which has different medicinal and traditional uses among different ethnic groups [1].

The genus Solanum is one of the large genera of flowering plants in the world, containing about 1500-2000 species. This genus is the largest among Solanaceae family and one of the top 10 genera of the world's plants in terms of species number [2].

Solanum is derived from the Latin name solamen which means calming. This name refers to the medicinal effects of most herbs [3].
Different Solanum species are found in temperate and tropical climates at high temperatures with high morphological variation. The genus is considered to have one of the most important economic taxa in the world including some cultivated species in agriculture such as potato (S. tuberosum L.), tomato (S. lycopersicum L.), eggplant (S. melongena L.), and many more species used as food besides those which are fatal due to the presence of toxic substances and secondary compounds present in different pharmaceutical substances and also their consumption in pharmaceutical industries.

The section Solunum, typified by the black nightshade (Solunum nigrum L.) is one of the largest, most variable/widespread species of the genus Solanum L. Species belonging to this section are distributed in temperate to tropical regions of the world from sea-level to over $3000 \mathrm{~m}$ altitude. Their most important characterizations are as follows:

Unarmed herbs, sometimes suffrutescent, occasionally shrubs or epiphytes. Stems terete or angled, the angles with smooth or dentate ridges. Inflorescences 2-36 flowered, cymose, pedunculate; cymes umbellate to helicoid. Flower pentamerous; calyx campanulate-stellate, with broadly triangular to ovate-lanceolate lobes; corolla $<20 \mathrm{~mm}$ diameter, white to purple, often with a conspicuous basal star, stellate to rotate, the petals recurved; fruit succulent, 1-2 ocular, many-seeded, globose to ovoid, black, brown, red, orange, yellow or green berry, with or without sclerotic granules [4].

Solunum nigrum is native to Eurasia and introduced in the Americas, Australia, Asia and South Africa. Parts of this plant can be highly 
toxic to livestock and humans, and is also considered as an invasive weed. Nevertheless, ripe berries and cooked leaves are used as food in some locales; and plant parts are used as a traditional medicine [5]. Phytochemical investigation of whole plant reports that, it contains alkaloids, flavonoids, tannins, saponins, glycosides, proteins, carbohydrates, coumarins \& phytosterols. According to some investigations, Solanum nigrum and its related species also utilized as traditional remedy for ulcer, hepatotoxicity and cancer, employs various immunological applications in cancer and others. These plants are beneficial in preventing liver toxicity \& cytotoxicity thus, improving functions of liver and kidney also finds immense utility in abdominal problems, body pain, and central nervous system and brain functioning. Taking great concern of the useful benefits of the plants, they can be subscribed as a safe, highly important, medicinal plant for general mankind [6].

Recent studies show four new steroidal glycosides; alkaloids, solamargine, solasonine, $\alpha$ and $b$ solanigrinechez isolated by berries of $S$. nigrum. Chemical analysis of the methanol extract of root and stem shows a steroidal genin saturated identified as tigogenin (glycoside and two spirosestanol furostanol glycosides) by mixed melting point and IR spectroscopy [7]. Among new compounds recently experienced; solanigrosides- $\mathrm{CH}$ and degalactotigonin two steroidal saponins (called Nigrumnins I and II), two new disaccharides (BDthevetopyranosyl ethyl-(1-4)-BDoleandropyranoside and BDthevetopyranosyl ethyl-(1-4)-a-Doleand-ropyranoside) identified by spectroscopic methods [8]. The seeds of
S. nigrum have a high fat content and are considered as an important source of linoleic acid [9] which contains solanine, protein, oleic acid, palmitic acid, stearic acid and sitosterol. All parts and immature green contain steroidal glycosides as glycoalkaloids [10]. They are widely considered defensive allelochemicals of plants against pathogens and predators. In economic terms, they are used in place of steroid sapogenin diosgenin as raw material for the industrial production of corticosteroids. The main steroid alkaloids are solanine and solasonine [11-17].

So far, in Flora Iranica [18] and [19], five species have been reported and accepted from section Solanum in Iran, namely, S. nigrum, S. olgae, S. luteum, $S$. alatum and $S$. carmanicum. According to recent systematic studies in the world, S. olgae, S. luteum, $S$. alatum and $S$. carmanicum have been considered as synonyms of $S$. villosum that has yellow, orange or red fruits while in $S$. nigrum only black fruits are seen [20-21]. It should be noted that, $S$. carmanicum both reported in Flora Iranica as a type species of Iran but in Flora of Iran [19] it was synonym with $S$. alatum. The senior author is also currently studying the biosystematic and molecular biology of this genus in Iran to distinguish their species and the results will be published later. The fruit of this plant is green in the beginning and turns color when get ripens. In Iran, it is locally called "Taaj-rizi" or "Sag-angour" but in ancient books of traditional medicine, it has been named as "fox tail" or "fox grape". (Fig. 1). This plant is distributed in almost all regions of the country and in most cases grows as weed in farms and gardens (Map 1). 
Ethnobotanical Study ...
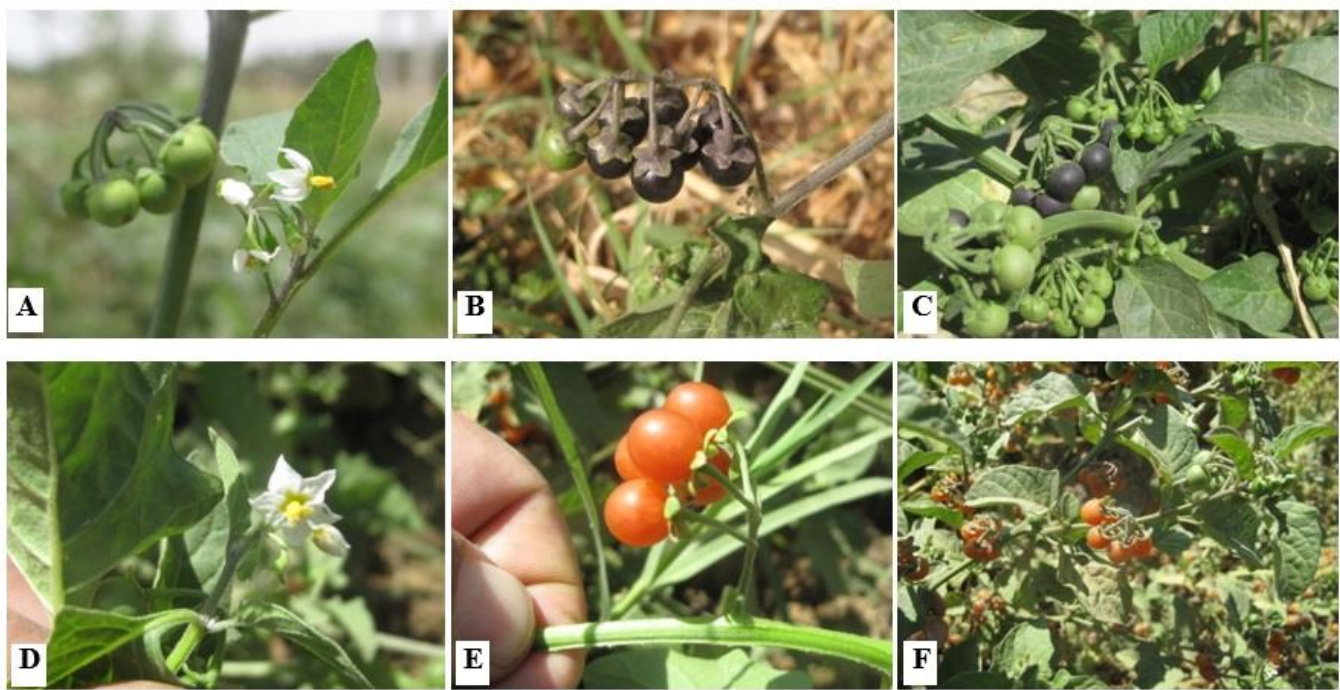

Fig. 1- Solanum nigrum (A. Flowers, B. Fruits, C. Habitat) and Solanum villosum (D. Flowers, E. Fruits, F. Habitat).
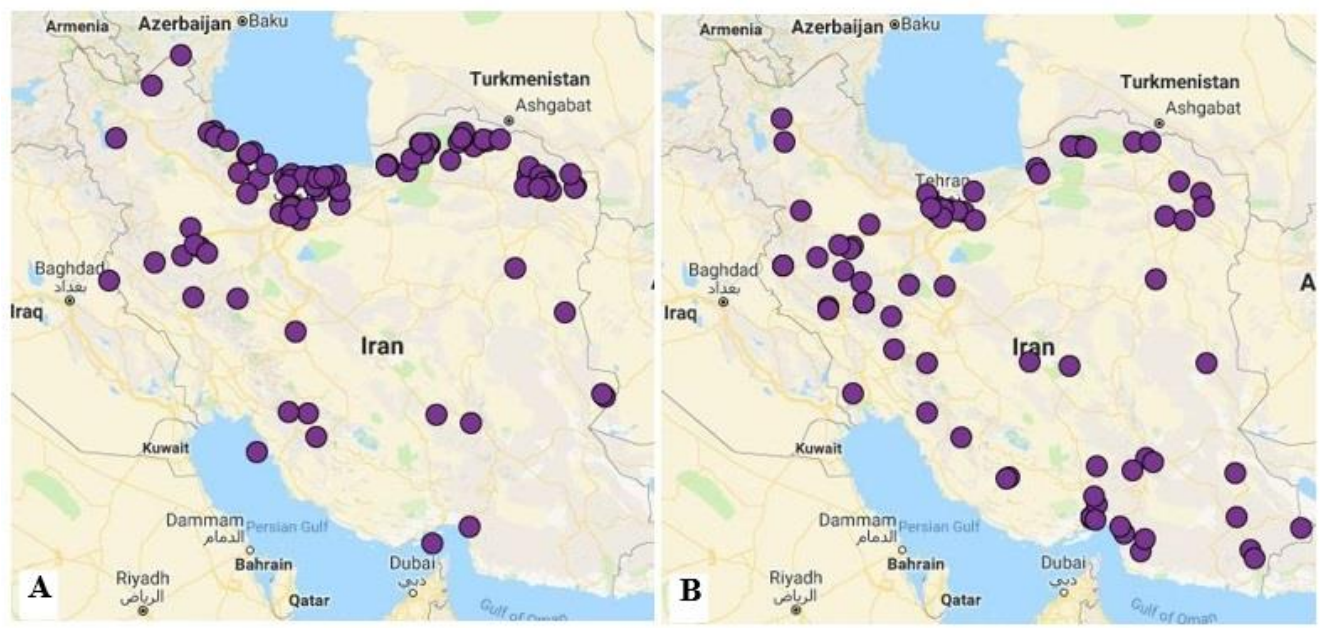

Map 1- Distribution of Solanum section Solanum in Iran. A: S. nigrum. B: S. villosum.

\section{Materials and Methods}

In this research, the wild species of Solanum in Iran was studied using field and library methods. In the field method, to determine the distribution of Solanum section Solanum, numerous trips to different parts of Iran were carried out and many samples were collected. After accurate identification with the help of usual methods, plants were transferred to the "IRAN" Herbarium. They were then sampled in different stages according to the principles of collecting plant specimens including drying and freezing for the inactivation of the pests. After receiving herbarium code, they were kept for further investigation. At least, one photograph was taken from each specimen. Additionally, information and reports related to Iranian specimens of Solanum section Solanum were studied in different herbaria including:

E (Royal Botanic Garden, Edinburgh), FAR (Kharazmi University), FUMH (Ferdowsi 
University), GUM (University of Guilan), Hamedan (Hamedan Agricultural Research Center), HAU (Alzahra University), HUMZ (University of Mazandaran), IAUH (Islamic Azad University, Olum-o-Tahghighat), IRAN (Iranian Research Institute of Plant Protection), K (Kew, Royal Botanic Gardens), TARI (Research Institute of Forests and Rangelands), TMRC (Shahid Beheshti University of Medical Sciences), TUH (Tehran University), and W (Naturhistorisches Museum Wien). (Table 1).

Besides, use of research methods in the field of ethnobotanical studies, scientific articles, authentic books and ancient documents have been studied in traditional medicine. In addition, the anthropological use of these plants has also been examined through interviews and questionnaires from local people, especially those of older drug dealers, native farmers and pharmacists. Native racial data was collected from 39 native people (22 females and 17 males). Ethnic data were collected using a pre-determined data collection questionnaire and open interviews (Fig. 2). In the library method, traditional Iranian books and published articles on the traditional and traditional uses of this drug in Iran have been studied. In this method, reviews and books of great scholars such as Abu Ali Sina [22], Herawi [23], Sahl-e Tabari [24] and Aghili Shirazi [25] have also been used.

Table 1- Specimens collected from Solanum section Solanum in Iran, respectively: Scientific name/Herbarium Code-

\section{Number:}

Solanum nigrum L.: E-00617872/ E-00617873/ FUMH-1168/ FUMH-1304/ FUMH-13650/ FUMH-23753/ FUMH-24594/ FUMH-27812/ FUMH-31822/ FUMH-38346/ FUMH-38419/ FUMH-41623/ FUMH-44972/ GUH-4173/ GUM-14270/ Hamedan5140/ Hamedan-5348/ Hamedan-5884/ IAUH-10122/ IAUH-10125/ IAUH-10128/ IAUH-10130/ IAUH-10131/ IAUH-10135/ IAUH-10143/ IAUH-1228/ IAUH-14370/ IRAN-26455/ IRAN-40474/ IRAN-40475/ IRAN-40477/ IRAN-40478/ IRAN-63838/ IRAN-65240/ IRAN-65334/ IRAN-65337/ IRAN-65339/ IRAN-65344/ IRAN-65345/ IRAN-65365/ IRAN-65388/ IRAN-65389/ IRAN-65449/ IRAN-65450/ IRAN-65455/ IRAN-74603/ IRAN-74604/ IRAN-74779/ IRAN-74787/ IRAN-74789/ IRAN-74790/ IRAN-74794/ IRAN-74827/ IRAN-74828/ IRAN-74829/ IRAN-74830/ IRAN-74831/ IRAN-74832/ IRAN-74833/ IRAN-74834/ IRAN-74899/ IRAN-74901/ IRAN-75313/ IRAN-75327/ IRAN-75627/ IRAN-75720/ K-001151674/ K-001151703/ K-001151707/ K-001151709/ K-001151710/ K-001151711/ K-001151715/ TARI-24399/ TARI-75847/ TMRC-0002397/ TMRC-0003375/ TMRC0003376/ TMRC-0003396/ TMRC-0003490/ TUH-29665/ W-1958-0003170/ W-1960-010737/ W-1964-0012563/ W-19650015232/ W-1965-0016921/ W-1967-0018776/ W-1969-0002497/ W-1972-0018107/ W-1976-0003450/ W-1999-0007529/ W-19990007532/ W-1999-0007533

Solanum alatum Moench (synonym: S. villosum Mill.): E-000251353/ IRAN-40444/ IRAN-40445/ IRAN-40446/ IRAN-40447/ IRAN-40448/ IRAN-40449/ IRAN-40451/ IRAN-450408/ IRAN-52407/ IRAN-52408/ IRAN-65336/ IRAN-65346/ IRAN-65445/ TARI-16153/ TARI-38074/ TARI-39751/ TARI-58319/ TMRC-0003176/ W-1958-0003171/ W-1958-0003537/ W-1958-0003676/ W-1958-0007258/ W-1960 -10978/ W-1960-0010977/ W-1958-0003537

Solanum luteum Mill. (synonym: S. villosum Mill.): E-00320659/ E-00617755/ E-00617779/ E-00617850/ E-00617888/ E00617890/ FUMH-11789/ FUMH-19183/ FUMH-23671/ FUMH-37029/ Hamedan-1431/ Hamedan-2674/ Hamedan-3662/ IAUH10123/ IAUH-10136/ IAUH-11730/ IRAN-65343/ IRAN-65421/ IRAN-65422/ IRAN-74184/ IRAN-74783/ IRAN-74786/ IRAN74835/ IRAN-74836/ IRAN-74837/ IRAN-74994/ IRAN-75900/ K-001151901/ K-001151904/ K-001151905/ TARI-1495/ TARI1637/ TARI-1684/ TARI-1684/ TARI-1979/ TARI-21705/ TARI-39717/ TARI-49638/ TARI-52364/ TARI-53353/ TARI-63672/ TARI-7442/ TARI-88973/ TARI-96883/ W-1951-0011012/ W-1960-0001502/ W-1965-0016922/ W-1971-0021658/ W-19720009540

Solanum olgae Pojark. (synonym: S. villosum Mill.): IRAN-40476/ IRAN-65338/ TARI-32530/ TARI-41033/ W-1968-0017994/ W-1968-17994/ W-1999-0007530 
Ethnobotanical Study ...

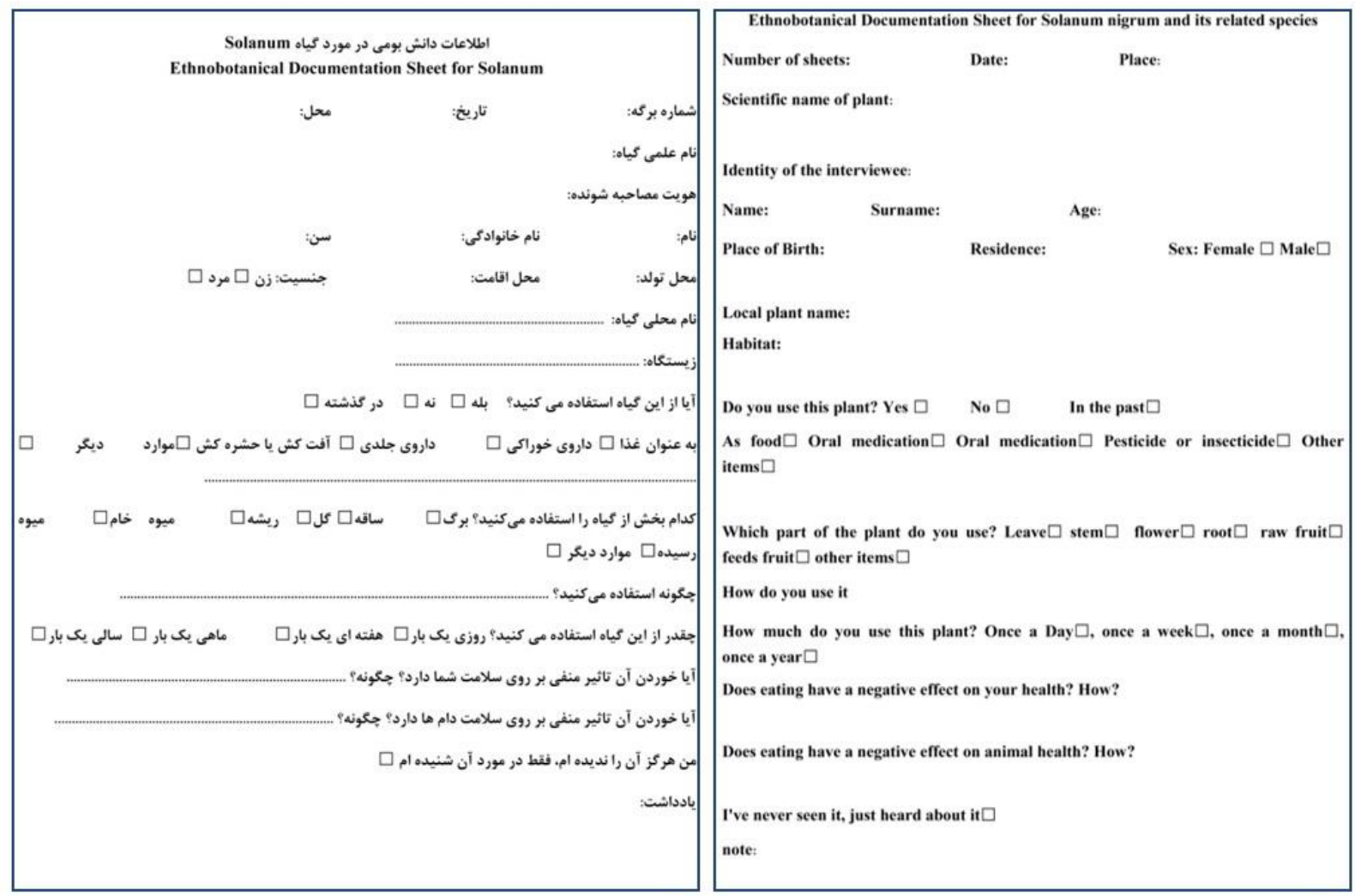

Fig. 2- Sample questionnaire form (in Persian and English languages).

\section{Results}

The results of this research are divided into following three parts:

The first part is the survey of questionnaires and public interviews on the medicinal properties of the plant. For the present study, 39 people of 11 different villages were interviewed. According to this survey, Solanum nigrum and its related species is the most commonly used for food digestion and constipation in traditional medicine and after that use for another the treatment such as analgesic and sedative, anemia, burns, carminative, cough, cut restoration, infections, mouth disinfection, skin diseases, toothache etc. (Table 2, Figs 3-4).

The second part identifies 180 different growing locations in Iran which generates their distribution maps. Of these, over 26 new samples were collected and identified by the authors; and while receiving the herbarium code, they were ultimately kept in the "IRAN" Herbarium. According to results obtained in second part, these plants are found in most parts of the country and so as weeds that grow in most parts of Iran at altitudes of 0-3100 m (Table 1).

Finally, the results of this study on ancient and traditional books and published articles of ethnobotany from different regions of Iran, is presented below:

The important aspect in the results of this research is that, medicinal and ethnobotany uses of the species available in the section Solanum in Iran, including S. nigrum and related species, showed equal therapeutic effects based on related references and questionnaires. These plants have been 
extensively used in traditional medicine in Iran for many ailment treatments such as toothache, gastrointestinal parasites, dysuria, bladder pain, cancer, voice problem, relieve pain, fat and glucose reducing etc.

Table 2- The results of the ethnobotanical questionnaires and interviews performed in this study

\begin{tabular}{|c|c|c|c|c|c|}
\hline Locality (Iran) & $\begin{array}{c}\text { Herbarium } \\
\text { Code }\end{array}$ & $\begin{array}{c}\text { Number of } \\
\text { People }\end{array}$ & Part Used & $\begin{array}{c}\text { Treatment of the } \\
\text { Disease }\end{array}$ & Preparation \\
\hline Alborz: Taleghan, Joestan & IRAN-74783 & 4 & $\begin{array}{l}\text { Leaves and } \\
\text { fruit }\end{array}$ & $\begin{array}{l}\text { Constipation } \\
\text { Burns } \\
\text { Infections }\end{array}$ & $\begin{array}{l}\text { Oral decoction } \\
\text { Balm } \\
\text { Balm }\end{array}$ \\
\hline Azarbaijan-W: Maku & IRAN-75720 & 4 & Leaves & Cut restoration & Balm \\
\hline Golestan: Kalaleh & IRAN-74604 & 3 & $\begin{array}{l}\text { Leaves and } \\
\text { fruit }\end{array}$ & $\begin{array}{l}\text { Skin diseases } \\
\text { Food digestion }\end{array}$ & $\begin{array}{l}\text { Balm } \\
\text { Oral decoction }\end{array}$ \\
\hline $\begin{array}{l}\text { Khorasan-N: Bojnurd, } \\
\text { Ashkhaneh, Aziz-abad }\end{array}$ & IRAN-74829 & 4 & Fruit & $\begin{array}{l}\text { Cough } \\
\text { Constipation }\end{array}$ & $\begin{array}{l}\text { Oral decoction } \\
\text { Oral decoction }\end{array}$ \\
\hline $\begin{array}{l}\text { Khorasan-N: Shirvan, } \\
\text { Honameh }\end{array}$ & IRAN-74835 & 3 & $\begin{array}{l}\text { Leaves and } \\
\text { fruit }\end{array}$ & $\begin{array}{l}\text { Skin diseases } \\
\text { Food digestion }\end{array}$ & $\begin{array}{l}\text { Balm } \\
\text { Oral decoction }\end{array}$ \\
\hline $\begin{array}{l}\text { Khorasan-R: Mashhad, } \\
\text { Torghabeh }\end{array}$ & IRAN-75627 & 3 & $\begin{array}{l}\text { Leaves and } \\
\text { fruit }\end{array}$ & $\begin{array}{l}\text { Cut restoration } \\
\text { Food digestion }\end{array}$ & $\begin{array}{l}\text { Balm } \\
\text { Oral decoction }\end{array}$ \\
\hline $\begin{array}{l}\text { Kohgiluyeh-o-Boyer } \\
\text { ahmad: Gachsaran }\end{array}$ & IRAN-74994 & 4 & $\begin{array}{l}\text { Leaves and } \\
\text { fruit }\end{array}$ & $\begin{array}{l}\text { Cough } \\
\text { Toothache } \\
\text { Mouth disinfection }\end{array}$ & $\begin{array}{l}\text { Oral decoction } \\
\text { Mouth balm } \\
\text { Mouth balm }\end{array}$ \\
\hline $\begin{array}{l}\text { Mazandaran: Juybar, } \\
\text { Kiakola }\end{array}$ & IRAN-74790 & 3 & $\begin{array}{l}\text { Leaves and } \\
\text { fruit }\end{array}$ & $\begin{array}{l}\text { Carminative } \\
\text { Anemia } \\
\text { Food digestion }\end{array}$ & $\begin{array}{l}\text { Oral decoction } \\
\text { Oral decoction } \\
\text { Oral decoction }\end{array}$ \\
\hline $\begin{array}{l}\text { Mazandaran: Savadkuh, } \\
\text { Zirab, Sorkh-kola }\end{array}$ & IRAN-74789 & 4 & $\begin{array}{l}\text { Leaves and } \\
\text { fruit }\end{array}$ & $\begin{array}{l}\text { Constipation } \\
\text { Anemia }\end{array}$ & $\begin{array}{l}\text { Oral decoction } \\
\text { Oral decoction }\end{array}$ \\
\hline Tehran: Darakeh & IRAN-74184 & 4 & $\begin{array}{l}\text { Leaves and } \\
\text { fruit }\end{array}$ & $\begin{array}{l}\text { Analgesic and } \\
\text { sedative }\end{array}$ & Balm \\
\hline $\begin{array}{l}\text { Tehran: Kahrizak, } \\
\text { Ghalehno, Haji musa }\end{array}$ & IRAN-74837 & 3 & fruit & $\begin{array}{l}\text { Constipation } \\
\text { Food digestion }\end{array}$ & $\begin{array}{l}\text { Ural decoction } \\
\text { Oral decoction }\end{array}$ \\
\hline
\end{tabular}

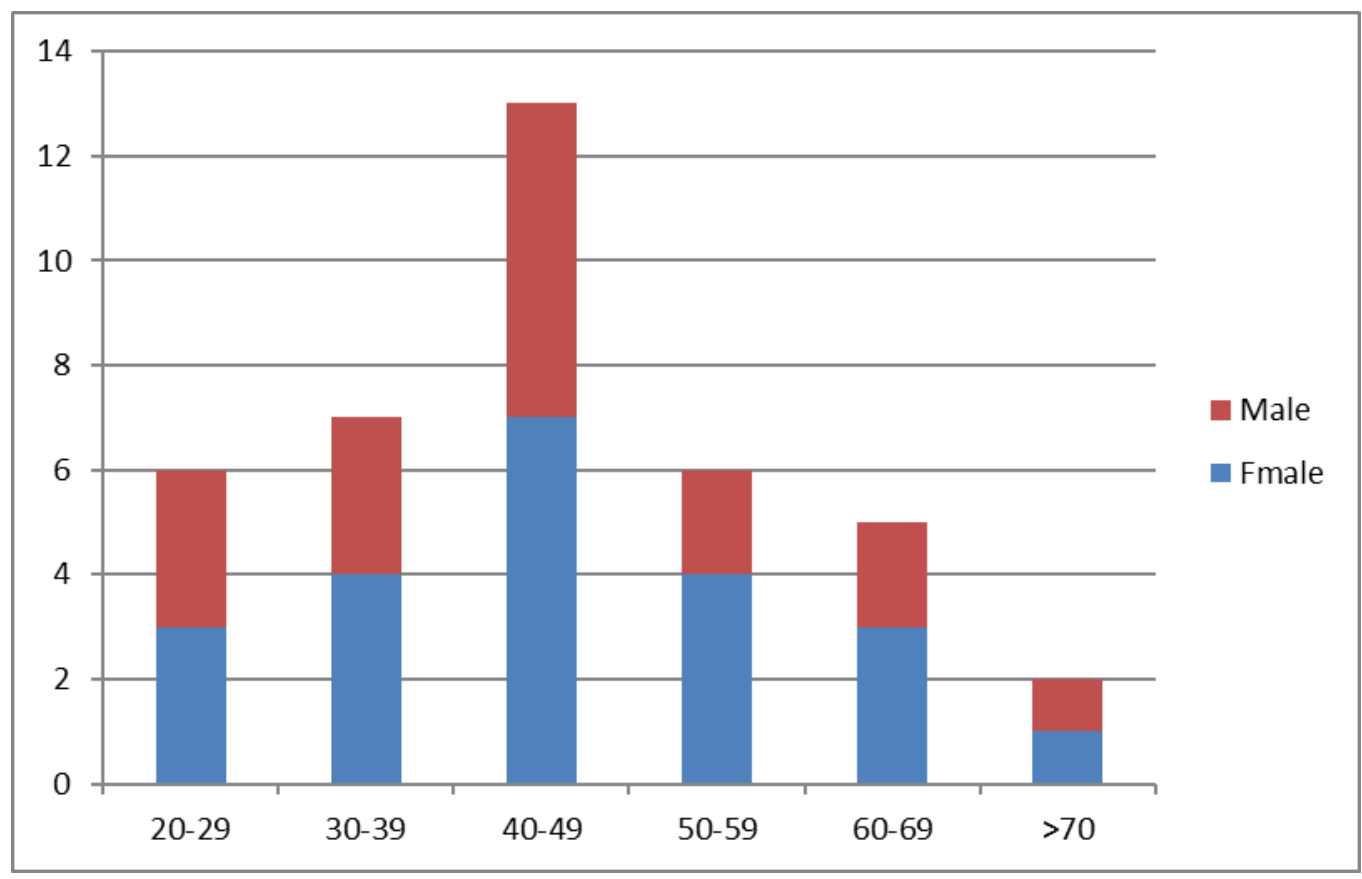

Fig. 3- Number of traditional healers by age category and gender 
Ethnobotanical Study ...

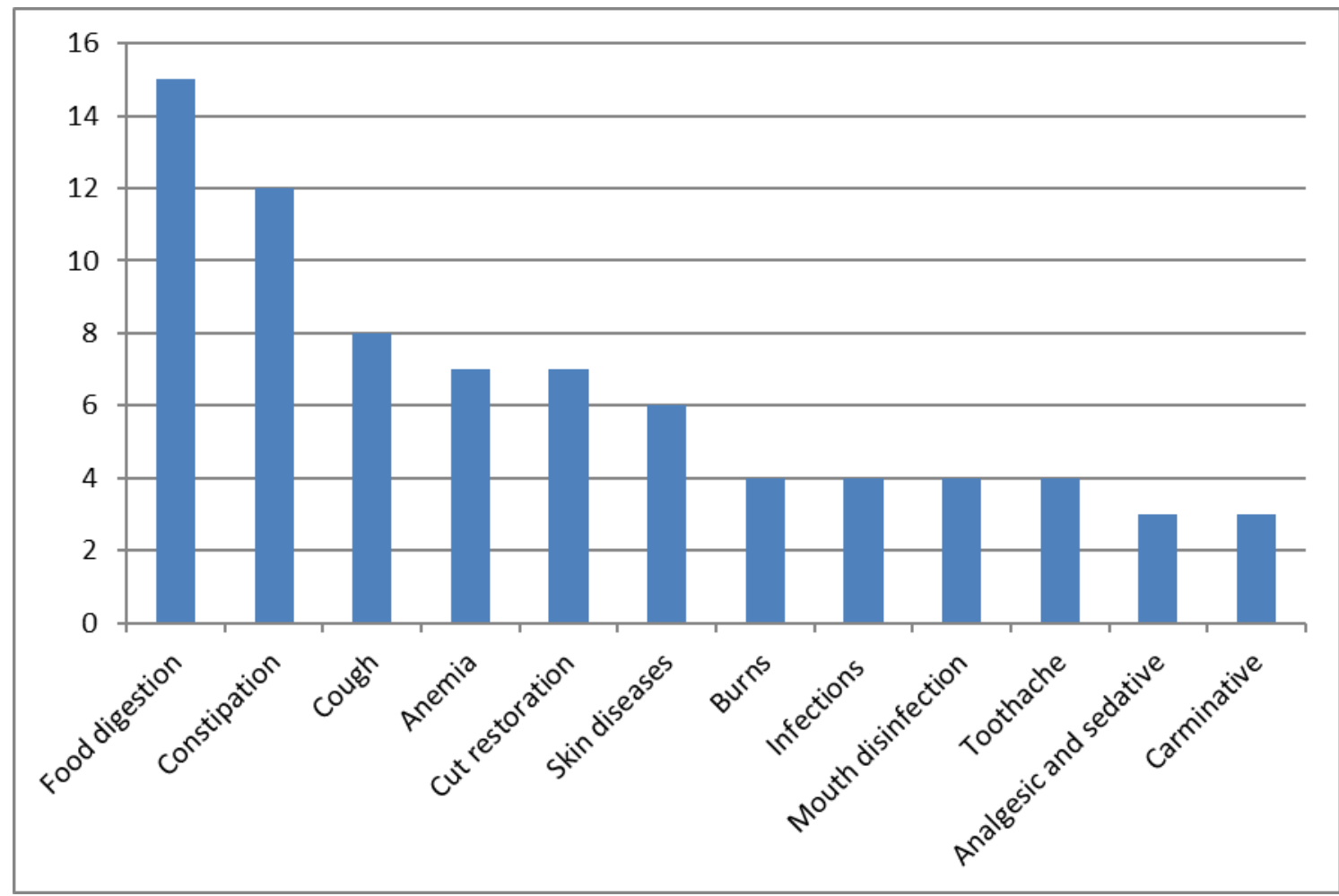

Fig. 4- Graph showing important diseases treated (based on ethnobotany questionnaire).

\section{Discussion}

The nature of the Solanum in traditional Iranian medicine is moderate and dry. The plant is also being used as fever-reducing agent, pain-reliever, softener, laxative, diarrhea, anticoagulant and anti-asthma. Eating a small amount of fresh fruit is needed to relieve constipation. Although, S. nigrum has a cold and dry temperament but it is believed that, it can sometimes have a hot nature too because of its steroidal structure which causes plants to have this antagonistic nature [25].

To use the plant, a three-hourly daily intake of 2-4 gm of dried fruit in a crushed form is recommended. Dried fruits of colorful vegetables (yellow, orange and red) are one of the most famous medicinal ingredients that are commonly used in conjunction with some other medicinal plants (e.g. Adiantum capillus-veneris L., Nepeta bracteata Benth., Cordia myxa L., Alcea digitata Alef., Ziziphus jujuba Mill. and Viola odorata L.). These combined drugs are commonly consumed in traditional Iranian medicine and are used as anti-fever, softener and laxative, especially for children.

The flowers and leaves of this plant are toxic and often used in different materials in external treatment. Compressed and dehydrated forms of dried plants are beneficial for influenza, intense running-nose and headache. Also, boiled parts of the plant are suitable for relieving muscle bumps and stiffness and help removing some itching. Leaf scrubs and fresh flowers are useful externally to relieve rheumatic and articular pains, burn injuries, smallpox, swelling and 
cancer pain. It should be noted that, due to the presence of a toxic substance called solanine in this plant, it should be used in a small amount and in a short period of time. It can occur naturally in any part of the plant, including the leaves, fruit, and tubers. Solanine has pesticidal properties which is one of the plant's natural defenses. It is worthy to note that, solanine was first isolated in 1820 from the berries of the European black nightshade (Solanum nigrum), after which it was named for [26]. It belongs to the chemical family of saponins. The toxicity is higher in leaves and flowering branches, therefore, overdosing should be treated with caution. Using more than $20 \mathrm{gm}$ is fatal, with dystonia and tongue fever, hiccups, vomiting, and mucus secretion symptoms which are similar to milk in the mouth [25].

In ancient Iranian traditional medicine, many scholars such as Avicenna [22], Herawi [23], Sahl-e Tabari [24] and Aghili Shirazi [25] have mentioned about the properties of this plant and its combination with other plants. Galen quoted by Mohammad Zakaria Razi "the combination of this plant is suitable for the thyroid gland disease treatment, meningitis, ear and chronic erythrocytes of the eye and uterus". Sahl-e Tabari has stated that, S. nigrum is cold, delicate and drytempered and is useful for liver and stomach inflammation recommending its roots cooked with salt, mixed with mint and black cumin. Abu Mansour Herawi, the author of the oldest remnant "Pharmaceutical-letter" in Persian (4th century), also believes in cold and drynature of this plant and recommends its extract for making suitable ointments to cure swollen skins. Hooper \& Field [27] reported the edibility of $S$. nigrum in Iran, affirmed that "Iranian women in the rural areas, consume its leaves just like spinach, and also use it to improve skin freckles". In India, the whole plant is used but fruits of black color are not consumed as they possess toxicity, although reddish brown-coloured fruits are edible [28].

Some of the uses of herbal medicine of $S$. nigrum and related species in different regions of Iran are as follows: Fruits used by Kurdish community in Dehloran and Abdanan districts, Ilam province (Western Iran) as medicinal plants for skin diseases, wound healing and eczema [29]. In the traditional medicine of Shiraz (Southern Iran) and Urmia (Northwest Iran), these plants are considered as antidiabetic herbs [29-31]. In Sirjan (Kerman province) the fruits are used to improve toothache and gastrointestinal parasites [32]. In Kohgiluyeh-o-Boyer Ahmad province, fruits are eaten to cure constipation [33]. In Sistan and Balouchestan (Southeast Iran) and Mobarakeh (Isfahan), these plants are taken to relieve toothache and leaves and fruits are also used for hemorrhoid treatment [30, 34-35]. Flowers and leaves areused by the indigenous people of Mobarakeh (Isfahan province) for anti-parasite treatment [35]. In Urmia (Northwest of Iran), fruits and seeds are consumed in the form of decoction used as sedatives and antidepressant [36]. In Vameghabad-e Bidoieh (Kerman province), leaves are used for eye pain treatment [37]. In East Mazandaran province, these plants are used for gastrointestinal tract and anemia treatment [38]. In medicinal plants sold in 
markets of Mashhad (Northeast of Iran), fruits of $S$. nigrum are used for treatment of osteoarthritis, mastitis, expectorant, hypnotic, sedative and gastritis [39].

In general, based on the claims retrieved from oriental medicine, S. nigrum has been specially utilized for treatment of inflammation and edema [40]. It has been traditionally believed that, the plant demonstrated healing effects in burns and infections [41]. ITM physicians declared that, aqueous extract of $S$. nigrum leaves with its cool and dry temperament, has astringent and restraint effect, so it has been used as a swelling reliever in ITM burn prescriptions with Malva sylvestris L. or other ingredients $[22,25,42-44]$.
According to in vitro studies of this plant on the treatment of inflammatory bowel disease, methanolic extract; $S$. nigrum fruit is useful for free radical scavenging activities in the DPPH assay [45]. In addition, A glycoprotein (SNL glycoprotein) isolated from fruit of this plant has scavenging effects on both superoxide anion and hydroxyl radical [46].

Active anti-cancer effects have been reported from Solanom nigrum fruits. Antiproliferative effects of this plant showed a direct correlation with antioxidant properties. The herbs as natural antioxidants with limited side effects could potentially improve the outcome of human breast cancer therapy [47]. More information is provided in Table 3.

Table 3- Effects of traditional treatment of Solanum nigrum and its related species in ethnobotanical sources in Iran

\begin{tabular}{llll}
\hline \multicolumn{1}{c}{ Ailment Treatment } & \multicolumn{1}{c}{ Part Used } & \multicolumn{1}{c}{ Preparation } & Reference \\
\hline Analgesic and sedative & Leaves and fruit & Oral decoction and balm & $\begin{array}{c}22,25,30,39,42, \\
43,44,49,52,58\end{array}$ \\
\hline Antidepressants & Fruit & Oral decoction & 36 \\
\hline Antimalarial activity & Fruit & Extract & 56 \\
\hline Anti-parasite & Leaves and fruit & Oral decoction & 35 \\
\hline Carminative & Fruit & Oral decoction & 55 \\
\hline Chest conditioner & Aerial parts, leaves and fruit & Oral decoction & 51 \\
\hline Cut restoration & Fruit & Balm & 48 \\
\hline Decrease fat and blood glucose & Fruit & Oral decoction & 30 \\
\hline Effective on cough & Aerial parts, leaves and fruit & Oral decoction & $49,51,53,54$ \\
\hline Expectorant & Fruit & Oral decoction & 39,52 \\
\hline $\begin{array}{l}\text { Gastrointestinal tract to ease } \\
\text { food digestion }\end{array}$ & Root & Oral decoction & $23,24,32,38$ \\
\hline $\begin{array}{l}\text { Healing effect in burns and } \\
\text { infections }\end{array}$ & Leaves and fruit & Balm & 41 \\
\hline Hypnotic & & & 39 \\
\hline Inflammatory bowel disease & Fruit & Oral decoction & 45,46 \\
\hline Treatment of addiction & Fruit & Isolated glycoprotein & 36 \\
\hline Treatment of anemia & Fruit & Oral decoction & 38 \\
\hline Treatment of bladder pain & Aerial parts, leaves and fruit & Oral decoction & 50 \\
\hline Treatment of cancer & Aerial parts, leaves and fruit & Heated on embers, & 47,50 \\
\hline Treatment of children smallpox & Ripe fruit & decoction & 23 \\
\hline Treatment of constipation & Fruit & Oral decoction & 33,55 \\
\hline Treatment of diabetes & Aerial parts and fruit & Oral decoction & $29,30,31$ \\
\hline
\end{tabular}


Table 3- Continue

\begin{tabular}{llll}
\hline \multicolumn{1}{c}{ Ailment Treatment } & \multicolumn{1}{c}{ Part Used } & \multicolumn{1}{c}{ Preparation } & Reference \\
\hline Treatment of dysuria & Aerial parts, leaves and fruit & Oral decoction & 50 \\
\hline Treatment of eczema & Fruit & Balm & 47 \\
\hline Treatment of eye pain & Leaves & Balm & 36 \\
\hline $\begin{array}{l}\text { Treatment of gastritis and } \\
\text { stomach ulcers }\end{array}$ & Ripe fruit & Oral decoction & 23,38 \\
\hline Treatment of hemorrhoid & Leaves and fruit & Balm & 49 \\
\hline $\begin{array}{l}\text { Treatment of inflammation and } \\
\text { edema }\end{array}$ & Leaves and fruit & Balm & 39,40 \\
\hline Treatment of menorrhagia & Fruit & Oral decoction & 57 \\
\hline Treatment of osteoarthritis & Fruit & Balm & 39 \\
\hline Treatment of toothache & Fruit & Mouth balm & $19,23,35,49,54$ \\
\hline Treatment of voice problem & Aerial parts and fruit & Oral decoction & 50 \\
\hline $\begin{array}{l}\text { Treatment of warts and skin } \\
\text { diseases }\end{array}$ & Leaves and fruit & Balm & $23,27,48$ \\
\hline
\end{tabular}

\section{References}

1. Eskandari M. Hiking with the Plants of Iran (Field Guide Book). Iranshenasi Publisher. 2014, 396 pp. (In Persian).

2. Frodin DG. History and concepts of big plant genera. Taxon 2004; 53: 753-76.

3. Edmonds JM and Chweya JA. Black nightshades. Solanum nigrum L. and related species. Promoting the conservation and use of underutilized and neglected crops (Book). Institute of Plant Genetics and Crop Plant Research, Gatersleben/International Plant Genetic Resources Institute, Rome, Italy. 1997, 155 pp.

4. Edmonds JM. Taxonomic studies on Solanum

L. section Solanum (Maurella). Botanical Journal of the Linnean Society 1977; 75: 141-78.

5. Albouchi F, Attia M, Hanana $M$ and Hamrouni L. Ethnobotanical Notes and Phytopharmacologiques on Solanum nigrum Linn. (Family: Solanaceae). American Journal of Phytomedicine and Clinical Therapeutics 2018; 6: 1: 5

6. Saleem TS, Chetty MM, Ramkanth CS, Alagusundaram SM, Gnanaprakash MK, Thiruvengada K, Rajan VS and Angalaparameswari S. Solanum nigrum Linn. A Review. Pharmacognosy Reviews 2009; 3 (6): $342-5$.
7. Ravi V, Saleem TSM, Patel SS, Raamamurthy, $\mathrm{J}$ and Gauthaman K. Anti-inflammatory effect of methanolic extract of Solanum nigrum Linn berries. International Journal of Applied Research in Natural Products 2009; 2: 33-6.

8. Ikeda $\mathrm{T}$, Tsumagari $\mathrm{H}$ and Nohara $\mathrm{T}$. Steroidal oligoglycosides from Solanum nigrum growing in Azerbaijan. Biologicheskie Nauki 1992; 3: 15-8.

9. Ravi V, Saleem TSM and Maiti PP. Phytochemical and pharmacological evaluation of Solanum nigrum Linn. African Journal of Pharmacy and Pharmacol. 2009; 3: 454-7.

10. Ghani A. Medicinal Plants of Bangladesh. In the Asiatic Society of Bangladesh, Dhaka. 2003, $382 \mathrm{pp}$.

11. Schreiber K. Planta Medica. 1958; 6: 435-9.

12. Doepke W, Sabine D and Matos NZ. Chemistry 1987; 27: 64.

13. Yoshida K, Yahara S and Saijo R. Chemical and Pharmaceutical Bulletin. 1987; 35: 1645-8.

14. Doepke W, Sabine D and Matos NZ. Chemistry 1988; 28: 185.

15. Tomova M. Farmatsiya 1962; 12: 16-9.

16. Aslanov SM. Khim. Prir. Soedin. 1971; 5: 674.

17. Aslanov SM and Novruzov EN. The Alkaloids. Izv. Akad. Nauk Az. 1978; 3: 15-8. 
18. Schonebeck-Temesy E. Solanaceae. In: K.H. Rechinger (ed.). Flora Iranica. 1972, 100: 49-79. Graz. 19. Khatamsaz M. Solanaceae (No. 24) In: M. Assadi et al. (ed.). Flora of Iran. Research Institute of Forests and Rangelands. 1998, 114 pp.

20. Särkinen $T$, Poczai $P$, Barboza GE, van der Weerden GM, Baden M. and Knapp S. A Revision of the Old World Black Nightshades (Morelloid Clade of Solanum L., Solanaceae). PhytoKeys 2018; 106: 1-223.

21. Katambo M and Lawrence MA. Systematic Study of African Solanum L. Section Solanum (Solanaceae). PhD thesis, Radboud University, Nijmegen, Netherlands. 2007, 154 pp.

22. Avicenna. Al-Qanun fi Al-Tibb (The Canon of Medicine). Dar Ehia Al-Tourath Al-Arabi, Beirut. 2005; 1: 416-7; 2: 68-70, 177-8; 4: 15862, 223-5 (In Arabic).

23. Herawi AM. The drug store (The book of old ancient Iranian medicine). 970.

24. Sahl-e Tabari, A. Ferdos-ol Hekmat (The book of old ancient Iranian medicine). 9th Century. 850.

25. Aghili Shirazi MH and Makhzan-ul-Adviah. Iran University of Medical Sciences, Research Institute for Islamic and Complementary Medicine (1st ed.). Tehran. 2008; 445-7, 690-2, 951-3 (In Persian).

26. Desfosses, M. Extrait d'une lettre à $M$. Robiquet. In: Journal de Pharmacie de Belgique. 1820; 6: 374-6.

27. Hooper D and Field H. Useful plants and drugs of Iran and Iraq. Field Museum of Natural History. Botanical Series. 1937; 9: 71-241.

28. Rajani Chauhan KM, Aastha Shori R and Dwivedi J. Solanum nigrum with dynamic therapeutic role: a review. International Journal of Pharmaceutical Sciences Review and Res. 2012; 15 (1): 65-71.

29. Sadeghi E and Borjian A. Medicinal plants of Cheshme anger region (Shiraz). Journal of Plant Science and Res. 2013; 1 (7): 17-24
30. Dolatkhahi M, Ghorbani Nohooji M, Mehrafarin A, Amini Nejad GR and Dolatkhahi A. Ethnobotanical Study of Medicinal Plants in Kazeroon, Iran: Identification, Distribution and Traditional Usage. JMP. 2013; 2 (42): 163-78.

31. Bahmani M, Zargaran A, Rafieian-Kopaei $M$ and Saki K. Ethnobotanical study of medicinal plants used in the management of diabetes mellitus in the Urmia, Northwest Iran. Asian Pacific Journal of Tropical Medicine 2014; 7 (1): 348-54

32. Khajoei Nasab FK and Khosravi AR. Ethnobotanical study of medicinal plants of Sirjan in Kerman Province, Iran. Journal of Ethnopharmacol. 2014; 154 (1): 190-7.

33. Mosaddegh $M$, Naghibia $F$, Moazzeni $H$, Pirani A and Esmaeilia S. Ethnobotanical survey of herbal remedies traditionally used in Kohgiluyeh va Boyer Ahmad province of Iran. Journal of Ethnopharmacology. 2012; 141: 80-95.

34. Ghamari S, Mohammadrezaei-Khorramabadi $\mathrm{R}$, Mardani $\mathrm{M}$ and Shahsavari S. An Overview of the most Important Medicinal Plants with AntiToothache Property Based on Ethnobotanical Sources in Iran. Journal of Pharmaceutical Sciences and Res. 2017; 9 (6): 796-9

35. Mardani-Nejad Sh., Janghorban M. and Vazirpour M. Collection and identification of medicinal plants used by the indigenous people of Mobarakeh (Isfahan), southwestern Iran. Journal of Herbal Drugs 2013; 4 (1): 23-32.

36. Saki K, Bahmani M, Rafieian-Kopaei M, Hassanzadazar H, Dehghan K, Bahmani F and Asadzadeh J. The most common native medicinal plants used for psychiatric and neurological disorders in Urmia city, northwest of Iran. Asian Pacific Journal of Tropical Disease 2014; 4 (2): 895-901.

37. Vakili Shahrbabaki SMA. The Ethnobotanical Study of Medicinal Plants in (Dehe-lolo-vameghabad Bidoieh) Village. Kerman, Iran. Journal of Medicinal Plants and By-products 2016; 1: 105-11.

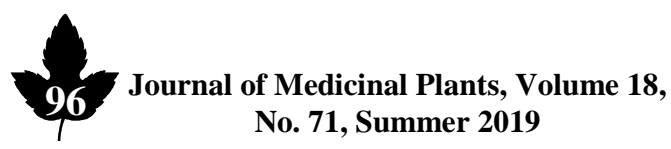


38. Ahvazi $M$ and Akbarzadeh $M$. Traditional Uses of some Medicinal Plants in Gastrointestinal tract Treatment in East Mazandaran (Iran). JMP. 2017; 16 (63): 43-56.

39. Amiri MS and Joharchi MR. Ethnobotanical investigation of traditional medicinal plants commercialized in the markets of Mashhad, Iran. Avicenna Journal of Phytomedicine 2013; 3 (3): 254-71.

40. Heo KS, Lee SJ and Lim KT. Cytotoxic effect of glycoprotein isolated from Solanum nigrum L. through the inhibition of hydroxyl radical-induced DNAbinding activities of NF-kappa B in HT-29 cells. Environmental Toxicology and Pharmacol. 2004; 17: 45-54.

41. Abas F, Lajis $\mathrm{NH}$, Israf DA, Khozirah $\mathrm{S}$ and UmiKalsom Y. Antioxidant and nitric oxide inhibition activities of selected Malay traditional vegetables. Food Chem. 2006; 95: 566-73.

42. Jorjani SE. Zakhirah-i Khvarazm Shahi. Bonyade Farhange Iran, Tehran. 1976, 593-4 (In Persian).

43. Ibn al-Baitar A. Al-jāmi li-mufradāt Aladwiyawa Al-aghdhiya. 1st ed. Iran University of Medical Sciences, Research Institute for Islamic and Complementary Medicine, Tehran. 2008, 2323, 291-3, 397-8, 502-4, 731-2 (In Arabic).

44. Fahimi Sh, Mortazavi SA, Abdollahi M. and Hajimehdipoor H. Formulation of a Traditionally Used Polyherbal Product for Burn Healing and HPTLC Fingerprinting of Its Phenolic Contents. Iranian Journal of Pharmaceutical Res. 2016; 15 (1): 95-105.

45. Al-Fatimi $M$, Wurster $M$, Schröder $G$ and Lindequist $\mathrm{U}$. Antioxidant, antimicrobial and cytotoxic activities of selected medicinal plants from Yemen. Journal of Ethnopharmacol. 2007; 111: 657-66.

46. Heo KS and Lim KT. Antioxidative effects of glycoprotein isolated from Solanum nigrum L. Journal of Medicinal Food 2004; 7: 349-57.
47. Hoshyar R, Mostafavinia SE, Zarban A, Hassanpour M, Partovfari M, Taheri A and Pouyan M. Correlation of Anticancer Effects of 12 Iranian Herbs on Human, breast Adenocarcinoma cells with antioxidant Properties. Free Radicals and Antioxidants 2015; 5 (2): 65-73.

48. Ghasemi Pirbalouti A, Momeni $M$ and Bahmani M. Ethnobotanical study of medicinal plants used by Kurd tribe in Dehloran and Abdanan districts, Ilam province, Iran. AJTCM. 2013; 10 (2): 368-85.

49. Iranmanesh $M$, Najafi $S h$ and Yosefi $M$. Studies on Ethnobotany of important medicinal plants in Sistan., Research Center for Medicinal Plants \& Ethno-veterinary, I.A.U., Shahrekord Branch, Iran. Journal of Herbal Drugs 2010; 1 (2): 58-65.

50. Maleki $T$ and Akhani $H$. Ethnobotanical and ethnomedicinal studies in Baluchi tribes: A case study in Mt. Taftan, Southeastern Iran. Journal of Ethnopharmacol. 2018; 217: 163-77.

51. Dolatkhahi M and Nabipour I. Ethnobotanical Study of Medicinal Plants Used in the Northeast Latrine Zone of Persian Gulf. JMP. 2014; 2 (50): 129-143.

52. Amiri MS, Jabbarzadeh $P$ and Akhondi M. An ethnobotanical survey of medicinal plants used by indigenous people in Zangelanlo district, Northeast Iran. Journal of Medicinal Plants Res. 2012; 6 (5): 749-53.

53. Mohsenzadeh A, Ahmadipour Sh, Ahmadipour S and Asadi-Samani M. A review of the most important medicinal plants effective on cough in children and adults. Der Pharmacia Letter 2016; 8 (1): 90-6.

54. Razmjoue D, Zarei $Z$ and Armand R. Ethnobotanical Study (Identification, Medical Properties and How to Use) of some Medicinal Plants of Behbahan city of Khuzestan Province, Iran. JMP. 2018; 4 (64 and 11): 33-49.

55. Khajoei Nasab F and Esmailpour M. Ethnomedicinal survey on weed plants in agro- 
Ethnobotanical Study ...

ecosystems: a case study in Jahrom, Iran.

57. Tansaz M, Memarzadehzavareh $\mathrm{H}$, Qaraaty Environment, Development and Sustainability. 2018; 1-20.

56. Feiz Haddad MH, Mahbodfar HR, Zamani $Z$ and Ramazani A. Antimalarial evaluation of selected medicinal plant extracts used in Iranian. Iranian Journal of Basic Medical Sciences 2017; 20: 415-22. M, Eftekhar T, Tabarrai M and Kamalinejad M. Menorrhagia Management in Iranian Traditional Medicine. eCAM. 2016; 21 (1): 71-6.

58. Abolhassanzadeh Z, Aflaki E, Yousefi GH and Mohagheghzadeh A. Medicinal Plants for Joint Pain in Traditional Persian Medicine. TiPS. 2016; 2 (2): 89-100. 